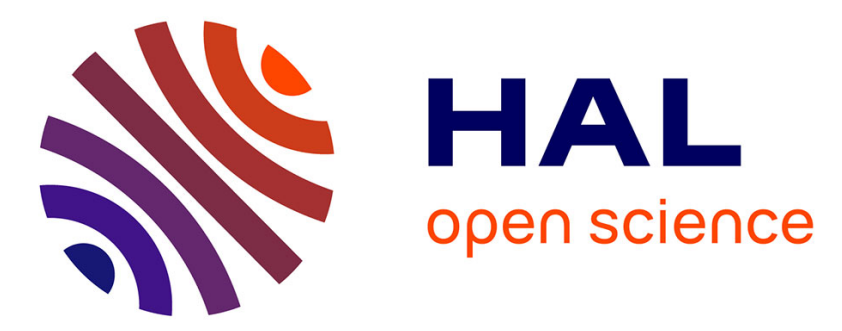

\title{
The European Bus with a High Level of Service (BHLS): Concept and Practice
}

Odile Heddebaut, Brendan Finn, Sébastien Rabuel, François Rambaud

\section{To cite this version:}

Odile Heddebaut, Brendan Finn, Sébastien Rabuel, François Rambaud. The European Bus with a High Level of Service (BHLS): Concept and Practice. Built Environment, 2010, Vol36 (n3), p307-316. hal-00614586

\section{HAL Id: hal-00614586 https://hal.science/hal-00614586}

Submitted on 12 Aug 2011

HAL is a multi-disciplinary open access archive for the deposit and dissemination of scientific research documents, whether they are published or not. The documents may come from teaching and research institutions in France or abroad, or from public or private research centers.
L'archive ouverte pluridisciplinaire HAL, est destinée au dépôt et à la diffusion de documents scientifiques de niveau recherche, publiés ou non, émanant des établissements d'enseignement et de recherche français ou étrangers, des laboratoires publics ou privés. 


\section{Built Environment, Lloyd Wright editor "Bus Rapid Transit: A public renaissance, Vol36 Number 3, 2010 article p307-316. \\ The European Bus with a High Level of Service (BHLS): Concept and Practice}

HEDDEBAUT Odile INRETS , FINN Brendan ETTS, RABUEL Sébastien CERTU, RAMBAUD François $C E R T U$

Dr. Odile HEDDEBAUT is Researcher at the French National Research Institute for Transport and Safety (INRETS) in the Department of Transport Economics and Sociology (DEST), 20 rue

Elisée Reclus BP317, 59666 Villeneuve d'Ascq Cedex, France. E-mail: odile.heddebaut@inrets.fr

Brendan FINN is Senior Consultant at ETTS Ltd, 24 Marley Court, Dublin 14, Ireland. E-mail: etts@indigo.ie

Sébastien RABUEL is Engineer, Project Manager at Center for Studies on Urban planning, Transportation and public facilities (CERTU), 9 rue Juliette Récamier, 69456 Lyon, Cedex 06, France E-mail: sebastien.rabuel@ developpement-durable.gouv.fr

François RAMBAUD is Engineer, Project Manager at Center for Studies on Urban planning, Transportation and public facilities (CERTU), 9 rue Juliette Récamier, 69456 Lyon, Cedex 06, France E-mail: francois.rambaud@ developpement-durable.gouv.fr

\section{Abstract}

The paper discusses the respective American Bus Rapid Transit (BRT) and European Bus with a High Level of Service (BHLS) concepts comparing their approaches and implementation conditions. It describes the main BHLS characteristics and the gains in ridership findings for several case studies among European countries.

Key words

BRT, BHLS, BHLS Characteristics, Implementation conditions, gains in ridership

\section{Introduction}

Since the 1990's throughout Europe bus improvements are observed and are currently called "Bus with a High Level of Service" (BHLS). Sweden has developed this concept with "trunk networks" in Stockholm and Gothenburg, BHLS lines in Jönköping and bus-only-roads as a pretram solution in Lund. In England and Ireland such systems are called "Quality Bus Corridor". France expands its concept of Bus à Haut Niveau de Service - (BHNS) in many cities of different sizes. Germany and Spain have their BHLS Metrobus concept and the Netherlands apply it under the name of "Hoogwaardig Openbaar Vervoer" (HOV). These countries have followed the same "systemic" approaches that seek to both increase the bus ridership and its quality of service and to adapt the bus offer to the European urban and economic context.

In order to study European BHLS implementation, to develop a comprehensive approach to bus provision and to sort out best practices, a collaboration among 14 European countries ${ }^{1}$ has been

\footnotetext{
${ }^{1}$ European participating countries: Belgium, Czech Republic, France, Germany, Greece, Ireland, Italy, Netherlands, Portugal, Romania, Spain, Sweden, Switzerland and United Kingdom,.
} 
launched through a $\operatorname{COST}^{2}$ Action approved in April 2007 called "Buses with a High Level of Service (BHLS): Fundamental characteristics and recommendations for decision-making and research". The objectives of this COST BHLS group are mainly to share the current state of the art and know-how in this field, to find and compare the key results as well as to understand the limits and difficulties of the BHLS implementation.

This paper presents firstly how the BHLS concept has emerged in Europe and the condition of its implementation. Secondly, it reports the main findings concerning the ridership gains for 10 of the specific BHLS bus lines.

\section{From the American Bus Rapid Transit (BRT) concept to the European Bus with a High Level of Services (BHLS) concept}

\section{The North American BRT concept development}

North American towns have developed with diffuse and low density suburbs that do not favor mass transit. Indeed, car ownership growth has led to the construction of large highways rather than the development of rail or public transport networks. In this context, Bus Rapid Transit firstly emerged in the form of bus lanes on freeways known as "busways" to improve the bus services and ease the Central Business District (CBD) access (Los Angeles in 1973 and 1979, Houston in 1979). Nevertheless, in the United States, these busways often have been turned into high occupancy vehicle (HOV) lanes. This answer to the oil crisis has decreased bus performance (Vuchic et al., 1994) due to the loss of dedicated lanes.

Later, the BRT projects reappeared in the 1990's and focused on speed. BRT was then defined as "a rapid mode of transportation that can combine the quality of rail transit and the flexibility of buses" (Levinson et al., 2002). As their implementations increased in North and South America, the studies describe a wider spectrum of characteristics to define the BRT systems (Levinson et al., 2003a, 2003b, Diaz, 2009). They are ranked from "BRT-Lite" to "Full-BRT" depending on their components (Gray et al., 2006).

BRT-Lite is the "lower limit" of the BRT concept and must be as a minimum faster than a normal bus line (Levinson et al., 2003a). It is often achieved by greater stop spacing and priorities at junctions. These lines often have their own identity by using a brand name, logo and specific colors applied to buses and stations. BRT-Lite is the most common form of BRT in North America (the Vancouver B-line in 1996, Chicago since 1998, the MetroRapid Bus in Los Angeles since 2000, etc.).

Full-BRT represent the bus systems that can achieve metro-style performances. They necessitate full grade-separated transit ways, off-board fare collection, frequent and rapid services, modern and clean vehicles. Bogotá, Brisbane and Ottawa are the most famous Full-BRT examples described (Levinson et al., 2003a, Wright and Hook, 2007). This kind of BRT is not really implemented in the United States, but this model is greatly admired and represents the ultimate reference point. Its operational performance combined with its flexibility could be integrated into an environment achieving higher urban densities (Hoffman, 2008).

Recently, the intermediate "BRT-Heavy" concept has emerged, emphasizing the on-street dedicated right-of-way at the heart of the system to cut time and ensure regular services (Gray et

\footnotetext{
${ }^{2}$ COST Action is an intergovernmental European framework for international co-operation between nationally funded research activities. COST creates scientific networks and enables scientists to collaborate in a wide spectrum of activities in research and technology. COST activities are administered by the COST Office and is endorsed by the FP7. For further information, please visit: www.cost.esf.org
} 
al., 2006). Flagship projects such as the Cleveland Health Line and the Eugene EMX Green line should contribute to develop the BRT-Heavy concept. Sixty three percent of American BRT projects scheduled for completion by 2017 include dedicated right of ways as an integral component (Kantor, 2008).

American research is now turned towards the integration of BRT projects into urban planning with a systemic vision like any other rapid transit system (Vuchic, 2005). Moreover, the creation of a specific body able to involve all the stakeholders at all planning levels is seen as a condition for success (Arrillaga et al., 2004, Danaher et al., 2007). The most recent BRT studies focus on planning conditions, decision-making processes, BRT integration into existing networks, and the acceptability and image of these transportation systems (Golub et al., 2007, Wright and Hook, 2007). Studies are carried out about the perception of various public transportation systems in Los Angeles (Cain et al., 2010) and on the influence of BRT stations on property value in Pittsburgh (Perk et al., 2010).

Since 2005 , a French working group headed by the transport study organization CERTU ${ }^{3}$ has defined its own concept of BRT based on initial local experiences (the "new town" of Évry since the 1970s, the Trans-Val-de-Marne system of Greater Paris since 1993, TEOR in Rouen since 2001) and by adapting BRT to the French urban environment and "transportation culture" (Babilote and Rambaud, 2005). In 2007, this French group decided to share its experiences with 14 others European countries by launching a group of experts known as "Cost BHLS" (www.bhls.eu). Emerging from this group is a shared view on BHLS, albeit with some unique characteristics from one European country to the other.

\section{European BHLS as BRT inspired by tramways performance and adapted to the European urban context}

In the United States, public transportation essentially answers the needs of commuters headed downtown, from extremely scattered and often far-off starting points. The European urban models present relatively dense cities with narrow streets where most activities and residence are mixed. This has influenced the public transportation organization that takes advantage of concentrated flows. The demand for public transportation goes beyond peak hour commuting travel and covers all-day, evening and week-end use of the transit systems. In most European cities, the systems of metros, tramways and suburban trains already fulfill the needs of high capacity transit.

European tramways are light systems operating mostly via exclusive on-street right-of-ways (i.e. more like streetcars than fully-segregated light railways) and integrated into the city with atgrade junctions and accessible platform. Capacity is limited by intersection management, with maximum of 6,000 trips/hour/direction for a 45 meters (148 feet) long tram with a headway of 3 minutes. The tramway has reappeared in many cities where it had been dismantled, with a new high-performance and modern image and with a strong linkage to enhanced streets. At the same time, buses generally suffer from a negative image due to congestion, irregularity, discomfort and outdated designs.

The emergence of the BHLS concept in Europe can therefore be explained by the necessity to fill the gap between the regular bus and the tramway in terms of performance, cost and capacity. Thoroughfares not served by metros or tramways usually present a relatively low user-potential, which does not justify the higher tramway capacity associated to higher cost (€15-30 million per $\mathrm{km}$, or $\$ 30-70$ million per mile). The BHLS approach tries to link advantages of an economical

\footnotetext{
${ }^{3}$ CERTU: Center for Studies on Urban planning, Transportation and public facilities.
} 
bus-based system and performances of heavier systems. It has been inspired by American BRT with regard to methodology and design, favoring a transportation system in which the vehicle is but one of various components. Just like BRT, BHLS remains generic and can be integrated into any type of infrastructure configuration.

\section{European BHLS: a different choice of components compared to the American approach}

In general, very high-capacity configurations using grade-separated transit ways do not suit the European urban context (lack of available space, undesirable urban cuttings, low demand). Nevertheless, inspired by tramways projects, the on-street exclusive lane constitutes the fundamental component allowing greatest speed and regularity gains, and the possibility to share again the streets in favor of alternative modes (walking and cycling ) despite occasional implementation difficulties (Heddebaut, 2007). BHLS can be implemented into congested zones, such as city centers. Moreover, the European concept of BHLS allows for a certain permeability of the exclusive lane, useful in case of a limited but heavily used route (taxis, cyclists, deliveries).

In comparison, in the United States, despite wider and often less congested numerous avenues, the realization of on-street exclusive lanes remains limited. BRT systems more often use discontinuous and not well-marked bus-only lanes that are mostly limited to rush hours. Outside the CBDs, BRT circulation via reserved lanes is provided by the opportunity to re-develop unused railroads (Miami's South Dade Busway in 1997, the Pittsburgh Busway in 2000, the Los Angeles Orange Line in 2005, etc.) or to use freeway shoulders. Nevertheless, attitudes are progressively evolving. With the implementation of the EMX Green Line in Eugene in 2007 and the Healthline in Cleveland in 2008, the United States now has two BRT-Heavy projects using axial on-street exclusive lanes integrated into the urban environment (use of grass-planted lanes in Eugene, building-to-building regeneration on Euclid Avenue in Cleveland).

We can find other differences between the American BRT and the European BHLS characteristics, in addition to their approach to interpreting exclusive right-of-way. In Europe, increase in stop-spacing is blocked by the resistance of users - in particular, disabled persons while it is used by $89 \%$ of future American projects planned for 2017 or earlier (Kantor et al., 2008). Off-board payment which is rare in Europe should develop with public awareness of this measure's effectiveness ( $54 \%$ of the projects in USA). Lastly, while long commute times encourage Americans to retain a high number of seats in their vehicles, capacity needs and attempts to reduce costs lead to fewer seats in European vehicles. This design results in a higher proportion of standing passengers whose comfort could only be ensured by special modifications of the bus platform, generating additional costs.

While Full-BRT is not present in Europe, numerous systems approach BRT-Lite relying on a hierarchical organization of the bus network such as the blue buses of Stockholm (Sweden) since 1999, the Lianes of Dijon (France) since 2004, and the Linea Alta Mobilita in Italy (Prato, Brescia, Pisa). But most of the new projects more or less correspond to America's BRT-Heavy. That is the case in France with 9 systems in operation and over 20 planned (Rabuel, 2009). It is also present in the Netherlands (Amsterdam in 2001, Eindhoven in 2005), England (Leeds in 1998, Cambridge in 2009), Sweden (Gothenburg in 2003, (Bjerkemo, 2007)), and Germany (Hamburg in 2005), and is being developed in Spain (Castellón in 2008, projects planned for Madrid) and Italy (projects for Messina and Bologna). 


\section{Varying institutional frameworks and cultures that condition the emergence of BHLS in Europe}

Most European countries have legislation regulating the organization of public transportation. In these countries, BHLS services are scheduled, like tramways, within planning documents similar to urban travel plans (Finn et al., 2009).

However, this model does not apply to Great Britain. There, deregulation (outside the Greater London area) authorizes the implementation of bus routes on the initiative of the relatively numerous private operators. In this context, it is relatively difficult to establish a global, integrated approach that favors the emergence of BHLS as single routes on dedicated running ways with a very high level of speed, comfort and information. Local authorities can just improve the network's performance by setting up bus lanes or bus priorities at traffic lights without a systemic approach. The focus on right-of-way is also a characteristic of the Dublin manner to improve the bus quality but with a different reason due to the fragmented responsibilities between the infrastructure planning and the bus service planning. Quality Bus Corridors (QBC) were created in Dublin since 1997 and are based on strongly identified, multiroute bus-only lanes which can also be used by taxis and cyclists (O’Mahony, 2002).

Contrary to Americans, Europeans have some difficulties in implementing bus lanes on freeways. That could be explained by the low co-ordination between the numerous stakeholders (urban and non urban transport authorities, freeways and roads managers, financial bodies). Nevertheless, the few and recent experimentations (HOV lane on the A6 freeway in Madrid region, shoulder bus lane in A48 freeway in Grenoble region in France ) are showing a high potential for further development in Europe.

\section{Ridership gains achieved with BHLS}

BHLS in Europe is implemented for a wide range of objectives, as described above. Nonetheless, each system anticipates gains in ridership. To be more precise, the transportation, social, environmental or economic objectives can only be achieved when ridership gains are made. Two questions arise:

- whether BHLS really is effective in achieving ridership gains,

- which are the contributory factors to ridership gains.

The experience in Europe has been that BHLS systems do achieve ridership gains, and in some cases ridership can even double. BHLS systems frequently involve significant changes in structure and volume of service, in addition to the travel time and quality improvements. While improvement in each of these attributes is well known to increase ridership, the holistic approach appears to achieve ridership gains which are "more than the sum of the parts".

To illustrate the European experiences, a set of 10 BHLS systems is presented in Tables 1 and 2 below. Table 1 presents primary characteristics of the BHLS systems, including the system length, nature of the running way, daily carryings and service headway during the peak periods.

Table 2 presents changes in ridership for each of the 10 BHLS systems. This indicates growth in the range 20\%-134\%. Table 2 also presents likely explanatory factors for the ridership gains:

- \% change in the service supply (measured in vehicle-kms)

- \% change in operating speed or journey time

- scale of change in service headway

- whether there was significant change to the network and/or route structure 
- whether there was significant change to the tariff structure or average tariff

- whether the BHLS was given unique branding and strong marketing

While we do not have full comparative data for all sites, we can make the following observations:

- BHLS system daily ridership is in the range 24,000 to 65,000 passengers/day. These data are for individual corridors, and hence matches or exceeds the ridership of many tramway and North American BRT systems.

- All of the BHLS systems achieve significant ridership gains, in the range $20 \%-134 \%$. It should be noted that this level of growth may be achieved over a number of years as the systems mature.

- BHLS systems invariably offer improved frequency and volume of service.

- In many cases the network and lines within the BHLS corridor have been restructured.

- In many cases, BHLS offers improved operating speed and journey time, although in a few cases there has been little improvement in speed/time but big improvement in both reliability and variance in journey times.

- All systems have a system identify and most have a unique brand and dedicated fleet. Marketing, image and product repositioning are a strong feature of BHLS systems.

It is clear that BHLS has achieved ridership gains and hence achieved many of its goals. Despite this, there is an extreme shortage of structured research into the individual and linked factors that achieve the ridership gains. This is urgently required to (a) assist future projects; (b) give better understanding of where funds are best targeted; and (c) provide feedback and evidence to policymakers and transport operators about the effectiveness of investment in BHLS.

\section{Conclusion}

The following key points can be highlighted: Successful BHLS projects require lengthy dialogue; the issue of choosing the right mode remains fundamental. As a mode, the bus appears flexible and well-adapted to new or progressive expanded urban zones (e.g. Almere in the Netherlands and the Fastrack project South-East of London).

Buses allow a variety of configurations: from high-volume primary routes fed by secondary services through to trunk sections shared by several routes in order to minimise transfers. However, in Europe there are no traces of the express services that are so widely developed in high capacity projects on the other side of the Atlantic.

Some BHLS projects are designed to be upgraded in future into tramway systems once there is sufficient demand. Europe's economic context and labour costs appear to favour tramway for upwards of 30,000 to 50,000 trips/day and for volumes of over 2,000 to 2,800 passengers per hour per direction.

These projects are beginning to show signs of the same high-quality integration as tramway can do; the exclusive running lanes are easily passable in order to promote cycling and walking. It then becomes difficult to go beyond three-minute headways on individual routes in order to maintain satisfactory service consistency.

A bus market specifically for BHLS appears to be emerging: this needs to be recognisable and provide the level of comfort and information of a structuring corridor. The bi-articulated vehicle also appears to have its place in Europe (Hamburg, Utrecht, Geneva). 
BHLS seems to have a highly promising market in Europe in towns, medium-sized conurbations as well as in the outlying zones of the biggest metropolitan areas. Until the expected publication of the COST Action report that will be published for the final seminar planed in Autumn 2011 to present the main findings and recommendations for decision-makers, do stay in contact through the website www.bhls.eu ${ }^{4}$, where you will find, amongst other information, all the presentations of the plenary workshops that have been and will be organised.

\section{References}

Arrillaga, B., Wnuk, L., Silver, F., (2004) Bus Rapid Transit Demand Analysis Update, Federal Transit Administration, Washington, D.C., USA,51 p.

Babilotte, C., Rambaud, F. (ed.), (2005) Bus with a high level of service: concept and recommendations Certu, Lyon, France, $111 \mathrm{p}$.

Bjerkemo, S.A., (2006) Avancerade kollektivtrafiksystem utomlands - mellanformer mellan buss och spårväg. Tillämpningsförutsättningar i Sverige., (Advanced public transport systems abroad - intermediate systems between bus and tram. Implementation prerequisites and possibilities in Sweden). VINNOVA rapport VR 2007:03. www.vinnova.se

Cain, A., (2010) Tangible and intangible service attributes Quantifying the importance of image and perception to Bus Rapid Transit, Paper presented to the 89th TRB Conference, Washington DC, January.

Danaher, A., Levinson, H., Zimmerman S., (2007) Bus Rapid Transit : Practitioner's guide, Transit Cooperation Research Program Report 118, Transportation Research Board, Washington, D.C., USA, 241 p.

Diaz, R. (ed.), (2009) Characteristics of Bus Rapid Transit for Decision-Making, Federal Transit Administration, Washington, D.C., USA, 410 p.

European Cooperation in Science and Technology (Cost) $\mathrm{n}^{\circ}$ TU0603, Bus with a High Level of Service, www.bhls.eu, Accessed March 12, 2010.

Finn, B., Heddebaut, O., Rabuel, S., van der Spek, D. and Brader, C. (2009) "Buses with High Level of Service (BHLS) - Operational, Regulatory and Contractual Dimensions". $11^{\text {th }}$ International Conference on Competition and Ownership in Land Passenger Transport (Thredbo series), Delft, 2009.

Golub, A., Miller, M.A., (2007) A decision-support tool for Bus Rapid Transit Systems deployment, revised paper submitted for Transportation Research Record, Transportation Research Board, Washington, D.C., USA.

Gray, G., Kelley, N., Larwin, T., (2006) Bus Rapid Transit, A Handbook for Partners, Mineta Transportation Institute Report 06-02, San Jose State University, 66p.

Heddebaut, O., (2007) Les difficultés de mises en œuvre des sites propres pour les modes de transport collectifs guidés ou non : le cas des lignes de bus à haut niveau de service, In Recherche Transport Sécurité, №94, pp. 27-45.

Hoffman, A., (2008) Advanced Network Planning for Bus Rapid Transit, The "Quickway" model as a modal alternative to "light rail lite", Federal Transit Administration, Washington, D.C., USA, 114 p.

\footnotetext{
${ }^{4}$ The first leaflet can be downloaded at http://www.bhls.eu/IMG/pdf/bhls nl1 gb web.pdf
} 
Kantor, D. (ed.), Moscoe, G. Silver, F., (2008) Bus Rapid Transit, Vehicle Demand and System Analysis Update, Federal Transit Administration, Washington, D.C., USA, 38 p.

Levinson, H.S., Zimmerman, S., Clinger, J., Gast, (2003a) Bus Rapid Transit: Synthesis of case studies. Transportation Research Record: Journal of the Transportation Research Board, No 1841, TRB, National Research Council, Washington, D.C., pp. 1-11.

Levinson, H.S., Zimmerman, S., Clinger, J., Gast, J., Rutherford, S., and Bruun, E., (2003b) Transit Cooperative Research Program, Report 90 : Bus Rapid Transit, Vol. 2: Implementation Guidelines, Transport Research Board, Washington DC, USA.

Levinson, H.S., Zimmerman, S., Clinger, J., Rutherford, S.C., (2002) Bus Rapid Transit: An Overview. In Journal of Public Transportation, 5 No2, pp.1-30.

O'Mahony, M., (2002) Quality Bus Corridors in Dublin, Journal of Transportation Research Record 1791, Paper $\mathrm{n}^{\circ}$ 02-3662, pp. 121-126.

Perk V., Mugharbel, M., Catala, M., (2010), Impacts of Bus Rapid Transit stations on surrounding single-family home values: study of Pittsburgh' East Busway, Paper presented to the 89th TRB Conference, Washington DC, January.

Rabuel, S. (ed.), (2009) Bus with a high level of service : choosing and implementing the right system Certu, Lyon, France

Vuchic, V.R, Bruun, E., Krstanoske, N., Euun Shin, Y., Kikuchi, S., Chakroborty, P., Perincherry, V., (1994) The Bus Transit System : its underutilized potential, Federal Transit Administration, Washington, D.C., USA, May, 77 p.

Vuchic, V.R., (2005) Métros légers et liaisons rapides par autobus, modes concurrents ou complémentaires? Transportation Public International, pp.10-13.

Wright, L., Hook, W., (ed.), (2007) Bus Rapid Transit planning guide, Institute for Transportation and Development Policy, $823 \mathrm{p}$. 
Table 1: Characteristics of selected BHLS systems in Europe

\begin{tabular}{|c|c|c|c|c|c|c|}
\hline CitY & SYSTEM IDENTITY & $\begin{array}{c}\text { SYSTEM LENGTH (KM)/ } \\
\text { (DEDICATED LANES) }\end{array}$ & NATURE OF RUNNING WAY & $\begin{array}{c}\text { PASSENGERS PER } \\
\text { DAY }\end{array}$ & $\begin{array}{l}\text { PEAK HEADWAY } \\
\text { (MINUTES) }\end{array}$ & DEDICATED FLEET? \\
\hline Amsterdam & Zuid-Tangent & $41(33)$ & $\begin{array}{l}\text { Bus-only road, bus lanes } \\
\text { (suburban/orbital) }\end{array}$ & 40,000 & 6 & Yes \\
\hline Dublin $^{1}$ & Quality Bus Corridor & $12(8.4)$ & Bus-lanes & 34,000 & $<1.5^{4}$ & No \\
\hline Gothenburg $^{2}$ & TrunkBus & $16.5(7.5)$ & Bus-lanes & 24,000 & 3.3 & Yes \\
\hline Hamburg $^{3}$ & MetroBus & $14.8(4.0)$ & Bus-lanes & 60,000 & 3.5 & Yes \\
\hline Helsinki & Jokeri Line & $28(6)$ & $\begin{array}{c}\text { Bus-lanes } \\
\text { (orbital route) }\end{array}$ & 25,000 & 5 & Yes \\
\hline Madrid & Bus-VAO & $16.1(16.1)$ & $\begin{array}{l}\text { Tidal segregated lanes } \\
\text { (motorway insertion) }\end{array}$ & $33,000^{5}$ & $<1^{4}$ & No \\
\hline Nantes & BusWay & $7(6)$ & Bus-lanes & 24,600 & 3.3 & Yes \\
\hline Paris & TVM & $20(19)$ & $\begin{array}{c}\text { Bus-only road } \\
\text { (suburban/orbital) }\end{array}$ & 65,800 & 3.5 & Yes \\
\hline Prato & LAM & $42(15)$ & Bus-lanes & $\mathrm{n} / \mathrm{a}$ & 7 & Yes \\
\hline Stockholm & Blue Line & $40(12)$ & Bus-lanes & $36,575^{6}$ & 5 & Yes \\
\hline
\end{tabular}

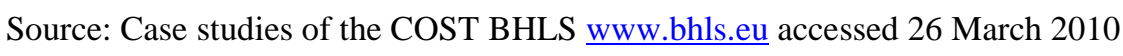

Notes:

1) Dublin data is for the Stillorgan Road Quality Bus Corridor, there are other QBCs.

2) Gothenburg data is for route 16, there are other TrunkBus lines.

3) Hamburg data is for the MetroBus Line 5; there are other MetroBus lines.

4) Dublin, Madrid systems operate multiple routes on their BHLS systems. Figure shows combined headway across all routes in direction of city centre.

5) The Bus-VAO system is tidal. Data shown is for inbound morning peak (0700-1000), for multiple bus routes and HOV occupants combined.

6) Passengers per day for Prato and Stockholm are averaged across multiple routes/corridors. 
Table 2: Ridership Gains and Related Factors for Selected BHLS Systems in Europe

\begin{tabular}{|c|c|c|c|c|c|c|c|}
\hline CITY & SYSTEM IDENTITY & $\begin{array}{c}\text { BHLS RIDERSHIP } \\
\text { CHANGE }^{2}\end{array}$ & $\begin{array}{l}\text { CHANGE IN } \\
\text { OPERATING } \\
\text { SPEED }^{3}\end{array}$ & $\begin{array}{l}\text { PEAK-PERIOd } \\
\text { HEADWAY } \\
\text { REDUCTION }\end{array}$ & $\begin{array}{c}\text { NETWORK } \\
\text { RESTRUCTURING IN } \\
\text { THE CORRIDOR? }\end{array}$ & $\begin{array}{c}\text { MAJOR TARIFF } \\
\text { RESTRUCTURING AS } \\
\text { PART OF BHLS? }\end{array}$ & $\begin{array}{c}\text { UNIQUE } \\
\text { IDENTITY FOR } \\
\text { BHLS SERVICES }\end{array}$ \\
\hline Amsterdam & Zuid-Tangent & $+47 \%$ & Significant & Yes & Significant & No & Yes \\
\hline Dublin $^{1}$ & Quality Bus Corridor & $+125 \%$ & Major & Yes & Minor & No & No \\
\hline Gothenburg $^{1}$ & TrunkBus & $+73 \%$ & Moderate & Yes & Significant & No & Yes \\
\hline Hamburg $^{1}$ & MetoBus & $+20 \%$ & Minor & Yes & Minor & No & Yes \\
\hline Helsinki & Jokeri Line & $+100 \%$ & Significant & $7 \Rightarrow 5$ & No & No & Yes \\
\hline Madrid & Bus-VAO & $+70-100 \%$ & $+80-100 \%$ & Yes & Minor & No & No \\
\hline Nantes & BusWay & $+55 \%$ & Moderate & Yes & Significant & No & Yes \\
\hline Paris & TVM & $+134 \%$ & Significant & $5 \Rightarrow 3.5$ & Significant & No & Yes \\
\hline Prato & LAM & $+57 \%$ & $+5 \%$ & $15 \Rightarrow 7$ & Major & No & Yes \\
\hline Stockholm & Blue Line & $+27 \%$ & 0 & Yes & No & No & Yes \\
\hline
\end{tabular}

Source: Case studies of the COST BHLS www.bhls.eu accessed 26 March 2010

Notes:

1) Data for Dublin, Gothenburg and Hamburg are for specific BHLS lines/routes; these are the 'flagship' BHLS lines in each city.

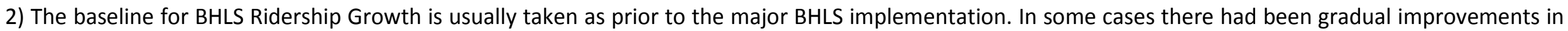
the preceding years, the baseline usually includes such improvements.

3) In some cases, the data was reported as changes in journey time 


\section{Illustrations:}

Photo 1 : Amsterdam Zuid-Tangent (photo: Stads-regioAmsterdam, 2008)

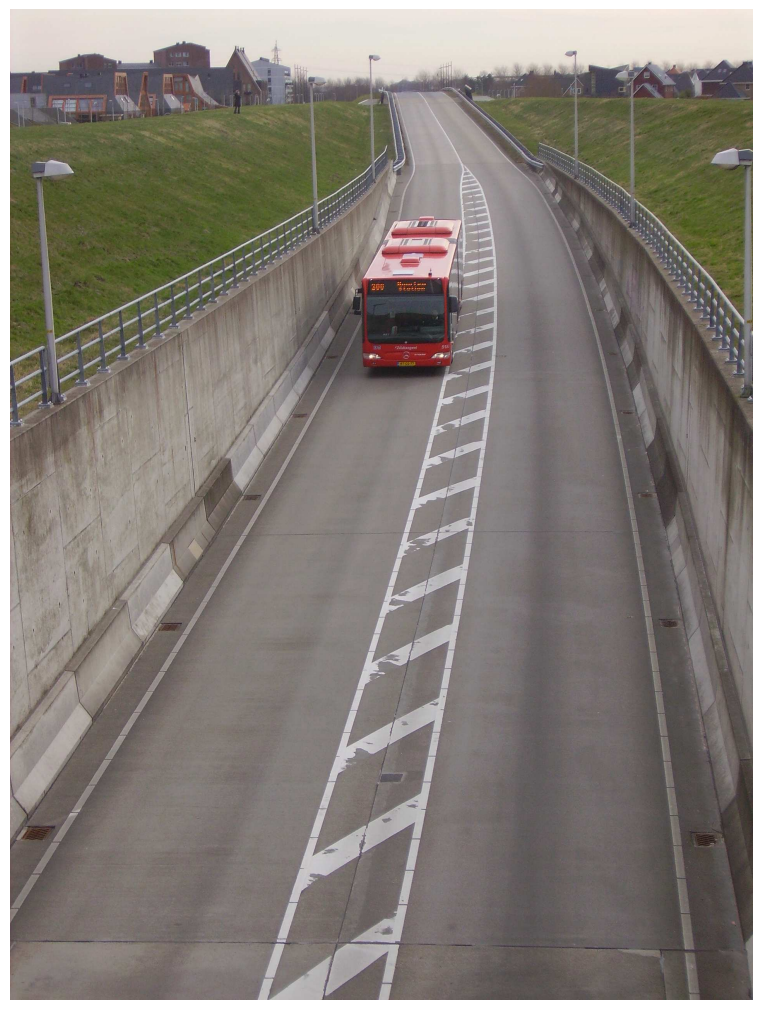

Photo 2: Dublin - QBC Stillorgan Road (photo: Sven Allan Bjerkemo, 2008)

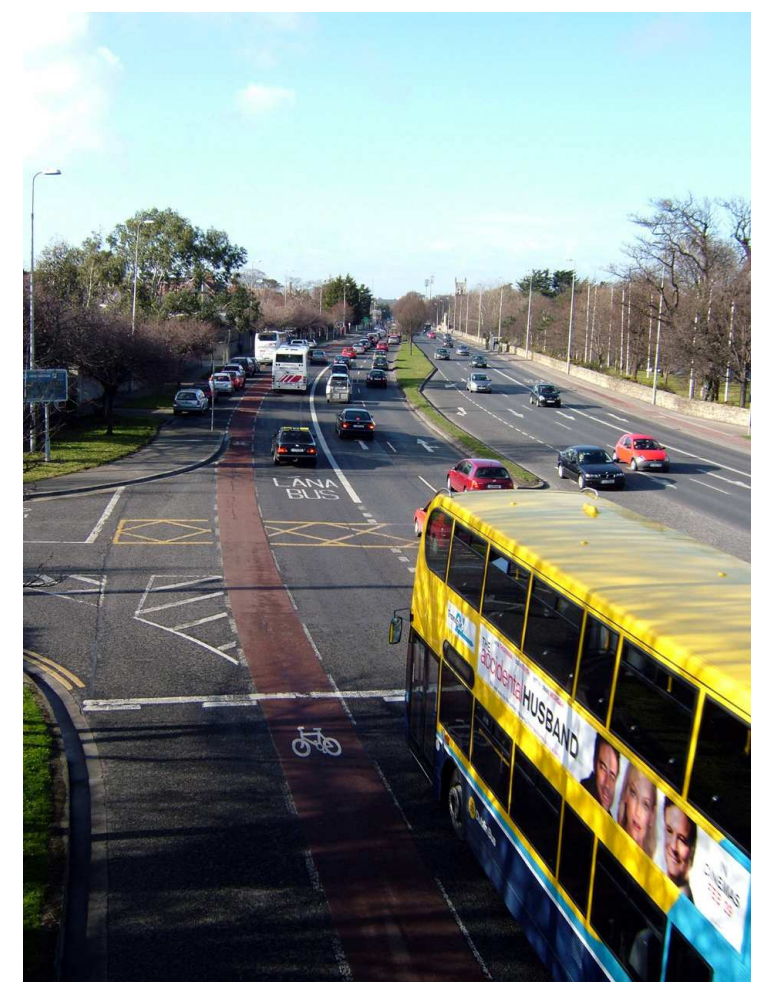


Photo 3: Hamburg - Metrobus XXL (photo: Thomas KNÖLLER October 2009)

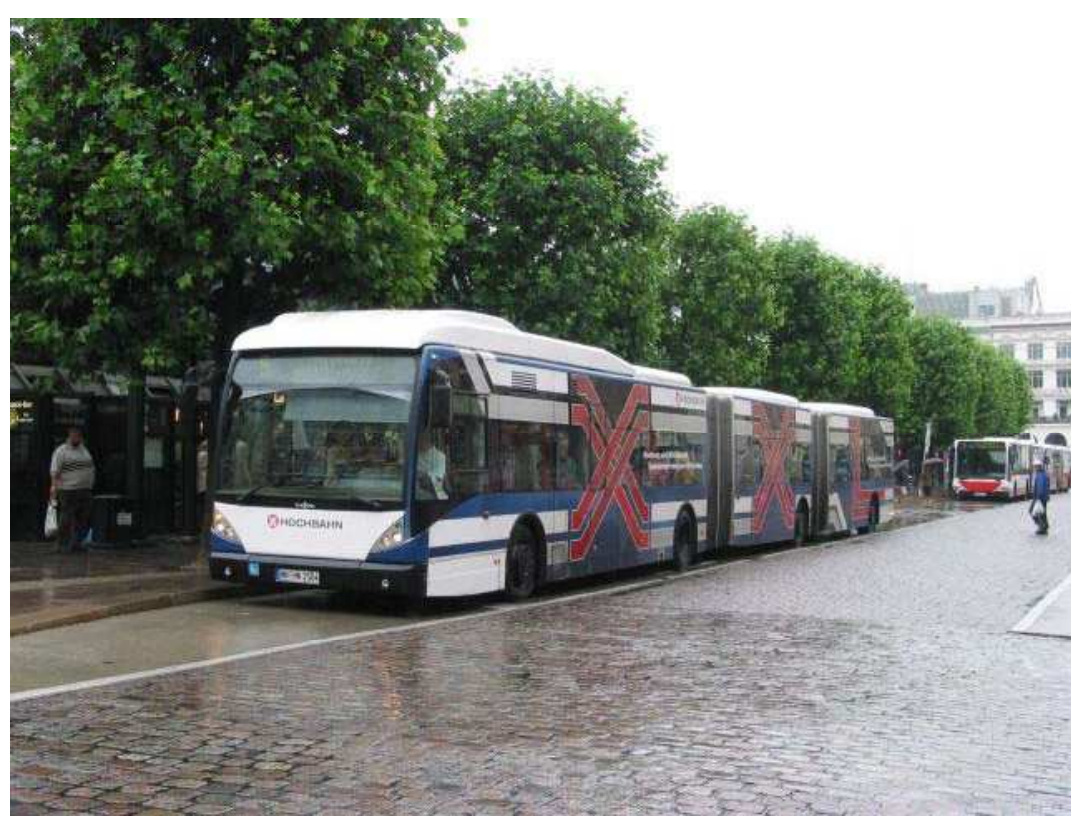

Photo 4 : Madrid Bus-VAO (Photo: CRTM Madrid October 2008)

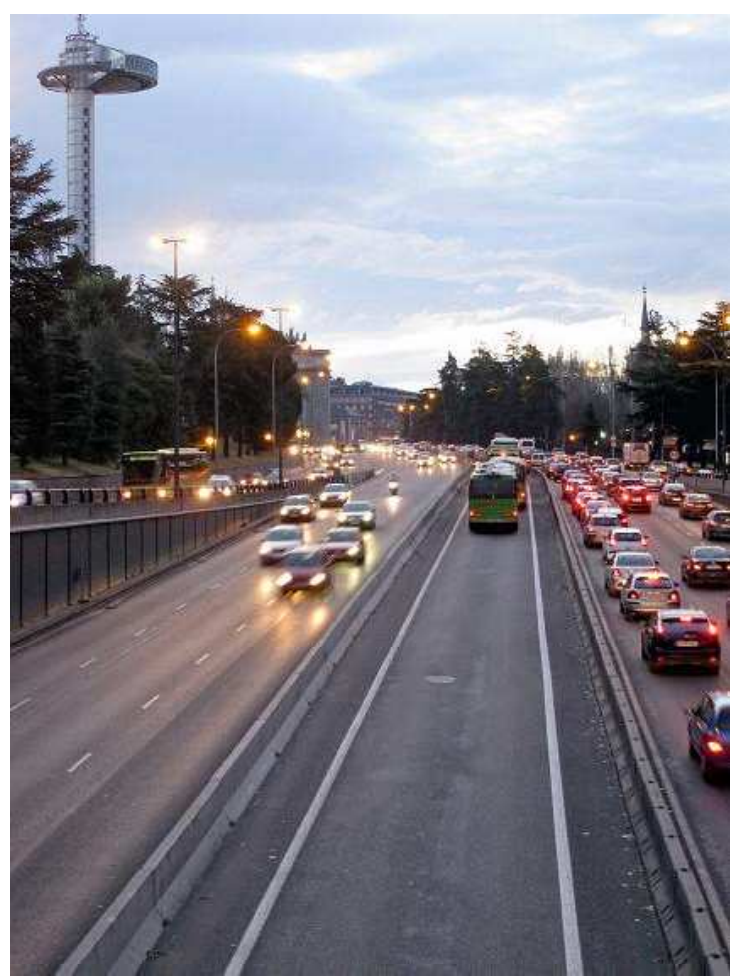


Photo 6: Nantes BusWay® 4 (photo: Odile HEDDEBAUT May 2008)

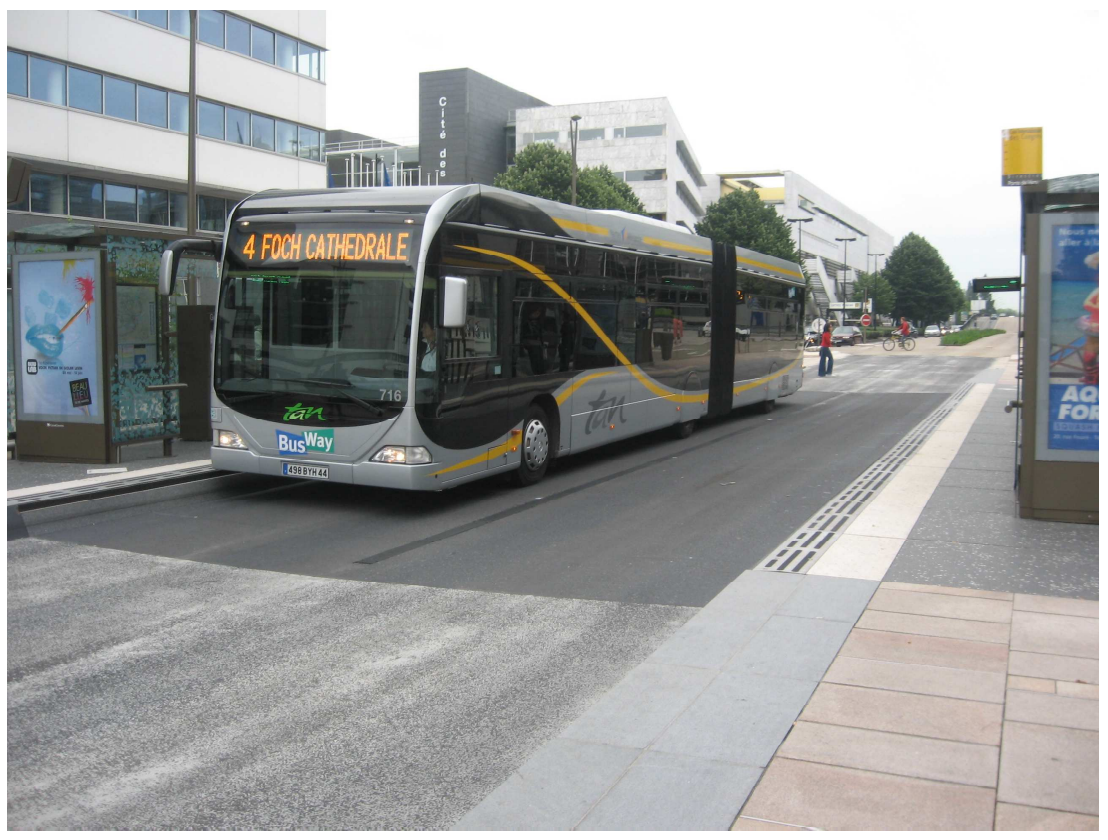

Photo 7: Paris - TVM (photo: Odile HEDDEBAUT May 2008)

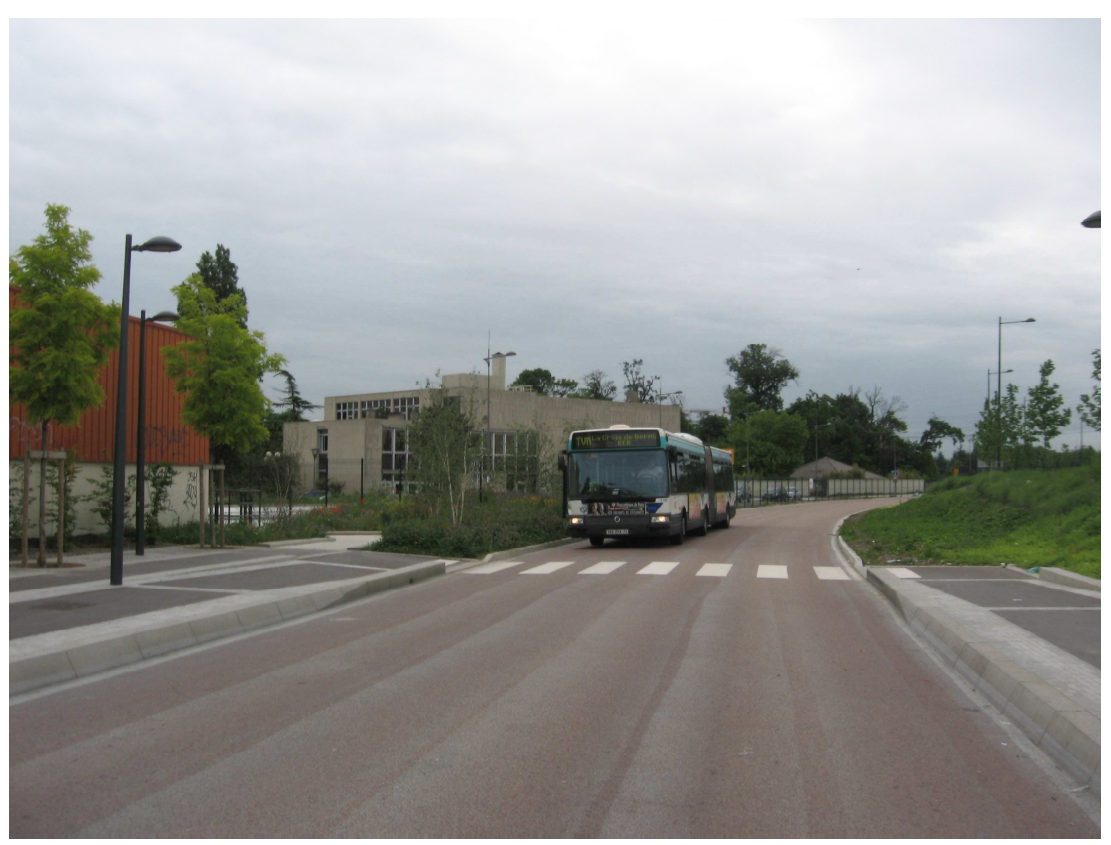


Photo 8 : Stockholm - Blue Line (photo: Odile HEDDEBAUT May 2009)

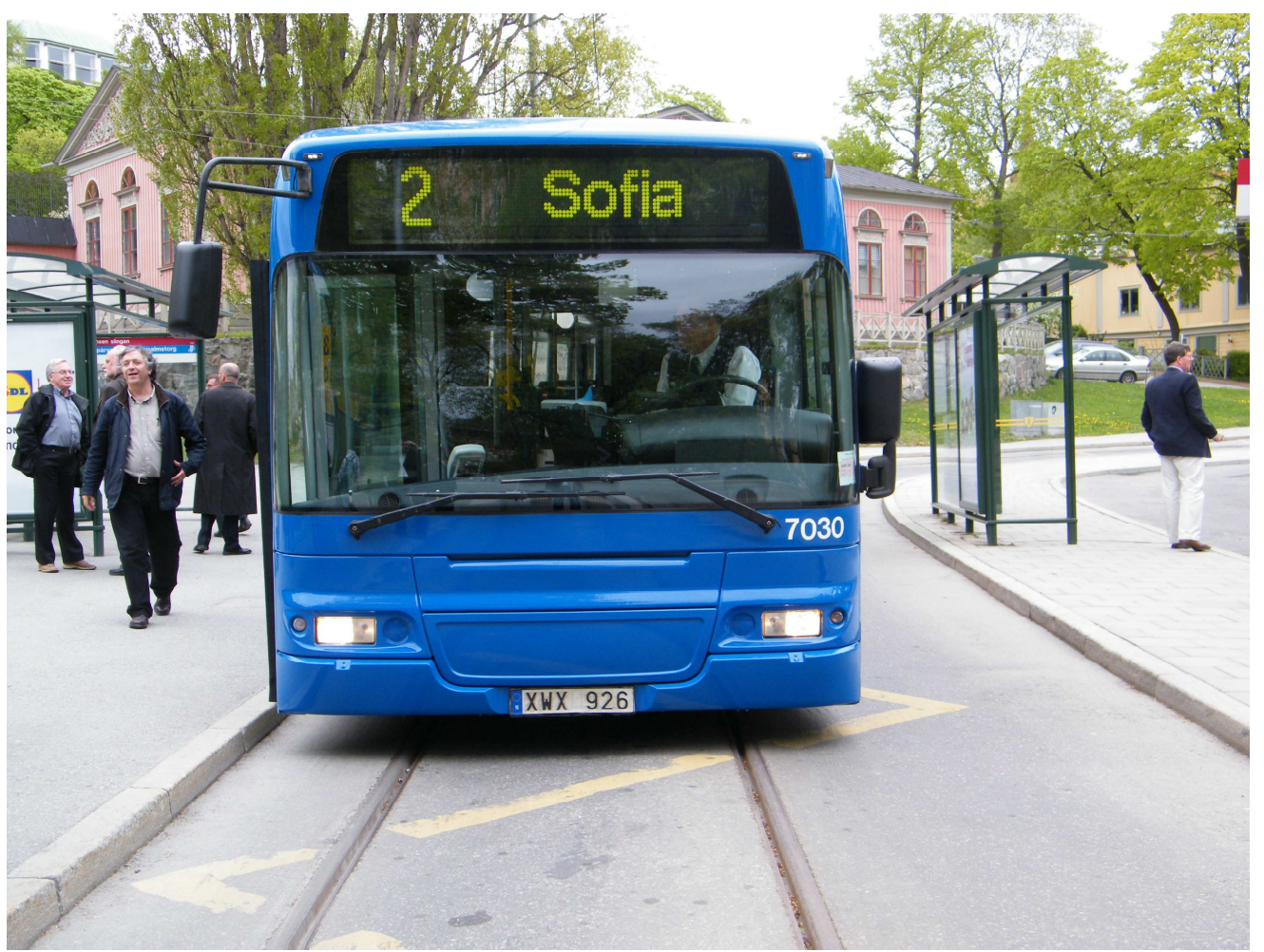

